\title{
Mucinous Cystadenocarcinoma
}

National Cancer Institute

\section{Source}

National Cancer Institute. Mucinous Cystadenocarcinoma. NCI Thesaurus. Code C3776.

An invasive adenocarcinoma characterized by cystic changes and the presence of

malignant glandular cells which contain intracytoplasmic mucin. It may arise from the ovary, pancreas, appendix, and lung. 